\title{
NEW HORIZONS IN INFRASTRUCTURE INVESTMENT - THE ASSENT OF THE ASIAN INFRASTRUCTURE INVESTMENT BANK AND ITS EFFECTS ON THE IMF AND THE USA
}

\author{
CHRISTA DENEVE*
}

\section{INTRODUCTION}

For decades there has been discourse on whether the International Monetary Fund ("IMF") is a useful tool for nations, or if the Fund hurts more than it helps. ${ }^{1}$ There has also been concern indicating that the United States has a hold on the international financial institution, which is supposed to be apolitical, unbiased, multilateral economic organization. ${ }^{2}$ This concern is found within the IMF's quota system and subsequently, voting rights. Each member of the IMF receives a set number of "base votes," and then a set of votes based upon that member state's quota share. ${ }^{3}$ The more quota share a state is assigned, the more votes the state receives. ${ }^{4}$ The top five quota contributors also receive their own representative in the IMF Executive Board, while other member states are represented by region, allowing for the highest quota contributors' interests to be better represented in the Executive Board's votes. ${ }^{5}$ Ayse Kaya claims that the closer a nation is economically aligned to the United States, the more likely it will receive favorable treatment in regard to quota assignment. ${ }^{6} \mathrm{~J}$. Lawrence Broz and Michael Brewster Haws find that the United States' domestic banks lobby on behalf of the IMF, and in return the United States influences the IMF to protect the areas where these banks are located internationally. ${ }^{7}$ The question then arises, if the IMF has effectively become an arm of the United States government, how could the IMF return to its intended apolitical, unbiased role?

This Note argues that recent competition from the Asian Infrastructure

* Doctor of Jurisprudence, 2020, Indiana University Robert H. McKinney School of Law; Bachelor of Science in Legal Studies, 2017, Ball State University. The author would like to thank Maxwell Huffman, who provided invaluable guidance and feedback, as well as board and members of the Indiana International and Comparative Law Review.

1. Thomas D. Willett, Understanding the IMF Debate, 5 THE InDEP. REV. 593-610, 596 (2001).

2. Id. at 595 .

3. $I d$.

4. Articles of Agreement of the IMF, art. $12 \S 5,2$ U.N.T.S. 39 https://www.imf.org/ external/pubs/ft/aa/pdf/aa.pdf.

5. Mark S. Copelovitch, Master or Servant? Common Agency and the Political Economy of IMF Lending, 54 INT'L STUD. Q. 49, 55-56 (2010).

6. Ayse Kaya, Power and Global Economic Institutions 11 (2015).

7. See generally J. Lawrence Broz \& Michael Brewster Hawes, Dept. of Pol. Sci., Univ. of Cal., San Diego, 8th Annual International Society for New Institutional Economics Conference (ISNIE), US Domestic Politics and International Monetary Fund Policy (Aug. 23, 2004), (Transcript available at http://pages.ucsd.edu/ jlbroz/broz_hawes_isnie.pdf [https://perma.cc/ WPN6-FQKW]). 
Investment Bank ("AIIB") is enough to incentivize the United States to relinquish some power and return the IMF to a more multilateral institution. The AIIB, having been founded in 2016, already has a growing membership outside of Asia. $^{8}$ At the time of this Note, the AIIB has twenty-six non-regional members, including a number of United States allies. ${ }^{9}$ The AIIB provides an alternative to IMF lending and gives states a larger share of basic votes $(12 \%$ as opposed to IMF's $5 \%$ ), giving more power to poorer nations in the AIIB as opposed to the IMF. $^{10}$

The most feasible way to counter rising competition would be for the United States to alter the quota structure to give more voting power (and in turn more power in general) to nations based on an increase to overall IMF quota, capping the gains nations can receive from the current IMF formula's openness variable, and removing the current formula's variability factor and transferring its weight to a blend of 50\% purchasing power parity ("PPP") GDP and 50\% GDP at market rates. PPP GDP shows how much one nation's currency can buy the same amount of goods and services in another nation's currency. ${ }^{11}$ GDP at market rates is simply the rate of the foreign exchange market over a period of time. ${ }^{12}$ The combination of the two at an even 50/50 percentage would address current legitimacy concerns surrounding the IMF by giving emergent nations more formal political power and mitigating their current grievances, as well as benefiting the United States through bolstering the IMF at a time when it is experiencing unprecedented competition from new international financial institutions.

While there is ample scholarship on the IMF's effects on the world economy and the United States' influence on the international financial institution, ${ }^{13}$ there is much less scholarship surrounding the prospect of competition in the international financial institution field. This is partially because the IMF has held a largely singular presence since the creation of the IMF at the Bretton Woods Convention. The only exception was a brief attempt at competition during the 1997 Asian Financial Crisis through the proposed Asian Monetary Fund..$^{14}$ The

8. See Members and Prospective Members of the Bank, Asian Infrastructure INVESTMENT BANK, https://www.aiib.org/en/about-aiib/governance/members-of-bank/index.html [https://perma.cc/4LXE-RRTT] (last visited Dec. 30, 2019).

9. Id.

10. Articles of Agreement of the AIIB, art. $28 \S 1$ (i).

11. Tim Callen, PPP Versus the Market: Which Weight Matters?, 44 Fin. \& DeV. Q. (Mar. 2007), https://www.imf.org/external/pubs/ft/fandd/2007/03/basics.htm [https://perma.cc/7Y3G995P].

12. Id.

13. See generally Y.V. Reddy, IMF: Concerns, Dilemmas, and Issues, 38 ECON. \& PoL. WKLy. 3304, 3304-14 (2003); Axel Dreher \& Jan-Egbert Sturm, Do the IMF and the World Bank influence voting in the UN General Assembly?, 151 PUB. CHOICE 363, 363-97 (2012); Mark S. Copelovitch, Master or Servant? Common Agency and the Political Economy of IMF Lending, 54 INT'L STUD. Q. 49, 49-77 (2010).

14. Shaun Narine, The Idea of an "Asian Monetary Fund": The Problems of Financial 
scholarship addressing the possibility of competition largely focuses on the Asian Monetary Fund, Japan's attempt at creating its own IMF alternative in the 1990s, which ultimately failed under pressure from the IMF and morphed into a complementary organization, the Asian Development Bank, instead of a directly competitive organization. ${ }^{15}$ More recent literature has begun to address the implications of a loss of hegemonic power of the United States, but there has yet to be research on how this loss of power in conjunction with the rise of the Asian International Infrastructure Bank will affect both the United States and the international financial scene as a whole.

Unlike past attempts, China has now succeeded in creating its own "IMF alternative" in the AIIB, and has also succeeded in gaining considerable membership. ${ }^{16}$ For example, as of January 21,2019 , the AIIB has a total of 44 regional and 26 non-regional member states. Among these states are South Korea, the United Kingdom, and Australia. ${ }^{17}$ This situation has never occurred before in the international financial system and the new competition presents a potentially feasible opportunity for the United States to willingly alter its power structure in a way that favors both the United States and states that have less voting power in the IMF. It also presents a new avenue to evaluate the rationalizations the IMF has asserted for its harsh conditions in return for emergency financing. With competition in the international financial lending market, the IMF and AIIB will be incentivized to give more favorable offers to recipient countries. However, the IMF claims its harsh conditions are necessary to fix the broken economies to which it lends its funds. ${ }^{18}$ With the AIIB taking a more collateral-based approach to lending, a major change to the understanding of international financial emergency lending may be afoot. ${ }^{19}$ The implications of the AIIB on the United States and the IMF are currently unfolding and could potentially change the entire structure of the international financial system.

This Note is organized as follows: Section I serves as an introduction to the IMF and AIIB. Section II explains the history of both the International Monetary Fund and the Asian Infrastructure Investment Bank. It addresses the concerns and criticisms of the IMF, specifically its issues with mission creep and conditionality. It also addresses the gradual approach the AIIB took in becoming a fully-fledged monetary fund through the Chiang Mai Initiative and subsequent

Institutionalism in the Asia-Pacific, 27 AsIAN PERSP. 65, 68 (2003).

15. Id. at $68-70,87$.

16. Articles of Agreement of the AIIB, supra note 10, at Schedule A.

17. See Members and Prospective Members of the Bank, supra note 8.

18. IMF Conditionality, INT'L MONETARY Fund (Mar. 5, 2019) https://www.imf. org/en/About/Factsheets/Sheets/2016/08/02/21/28/IMF-Conditionality [https://perma.cc/Y5NY7AST].

19. See generally Articles of Agreement of the AIIB, supra note 10; see also Joshua Miller, Africa in the News: Election Updates, Kenya's Mombasa Port, and Troops Withdrawn from Ethiopia-Eritrea Border, BROOKINGS (Dec. 22, 2018), https:/www.brookings.edu/blog/africa-infocus/2018/12/22/africa-in-the-news-election-updates-kenyas-mombasa-port-and-troopswithdrawn-from-ethiopia-eritrea-border/ [https://perma.cc/4JXY-VLG2]. 
Chiang Mai Initiative Multilateralization. Section III addresses the specific concern that the IMF is under largely United States control. It examines evidence of United States control through the leadership and organizational structure of the IMF that favor the United States. Specifically, this section examines the issues of voting power and quotas and the current formulae used to determine the power breakdown of the Fund, as well as the historical overlook of developing nations. Section IV addresses the history of the IMF formulae and subsequent singular formula that arose after the 2008 quota reform. It also proposes an alternative quota formula that may be able to be utilized to create a quota structure that more accurately reflects a nation's economic position and position within the IMF. Of all the proposed formulae for the $15^{\text {th }}$ General Review of quotas, the most advantageous for the United States and the IMF as a whole would be a combination of dropping variability, capping the gains on openness, and placing the weight of the variability factor into a blend of 50\% PPP GDP and 50\% GDP at market rates.

Section V examines why the AIIB differs from its predecessors and how the AIIB is an actual competitor to the IMF. This section distinguishes the AIIB from current regional monetary funds and explains why regional monetary funds are insufficient to create the type of competition that would create reorganization incentives in the United States. Section VI examines how competition from the AIIB can incentivize the United States to approve a substantial redistribution in quotas and voting power, and section examines the possibilities for the coming future for the AIIB, IMF, and international financial markets. Finally, Section VII concludes that the AIIB will provide sufficient competition to create reorganization in the international financial lending markets.

\section{HISTORY OF THE IMF AND AIIB}

\section{A. The IMF}

The International Monetary Fund was created following World War II in reaction to the financial difficulties that were in part responsible for the war. ${ }^{20}$ During the Bretton Woods Convention in Bretton Woods, New Hampshire, fortyfour state representatives met and agreed on a financial system that included fixing the price of the United States Dollar to the price of gold at $\$ 35$ per ounce. ${ }^{21}$ The IMF was intended to promote international monetary cooperation and exchange stability. Its creation also served to help establish an expansion of international trade and multilateral payments specifically through transactions between member states. ${ }^{22}$

However, as the global financial scene changed, the IMF followed suit. As

20. Willett, supra note 1, at 593.

21. Maria De Fatima Silva Do Carmo Previdelli \& Luiz Eduardo Simões De Souza, IMF, BIS, and World Bank: On the Intra-institutional Articulation of the International Financial System, 4 Mgmt. \& Econ. Res. J. 48, 50 (2018).

22. Articles of Agreement of the IMF, supra note 4, at art. I § (i), (ii), (iv). 
globalization of capital became the norm, the fixed exchange rate to gold began to fail. Globalization of capital provided unique difficulties in the isolation of current and capital accounts, as well as increased demands on the maintenance and oversight of these transactions. ${ }^{23}$ In 1976, following the Jamaica Agreement, the gold standard was abolished. ${ }^{24}$ Suddenly, the IMF's power was substantially expanded as the global financial markets embraced a floating exchange rate. ${ }^{25}$ Floating exchange rates, unlike fixed rates, can have its value change without central bank intervention. The currency is not tied to any other currency or bank. ${ }^{26}$

Because the IMF is an international organization, it does not have one single currency. Instead, its unit of measure is in Special Drawing Rights ("SDR"). These Special Drawing Rights refer to the rights of a nation to draw upon the resources of the IMF. During the gold standard, .888671 grams of fine gold was equivalent to 1 Special Drawing Right. ${ }^{27}$ Following the collapse of the gold standard, the value of Special Drawing Rights was affixed to a basket of currencies. These currencies include the United States Dollar, Euro, Chinese Yuan, Japanese Yen, and the Pound Sterling. Each currency is weighted depending on how much of that currency is in the "basket." The value of the basket is then fixed for five years, when the IMF reevaluates the SDR valuations. $^{28}$

At the time of its inception, the IMF mandated that its founders ensured would be narrowly tailored and strictly focused on the factors of stable exchange rates. Following the floating exchange rate, the IMF's established surveillance function could take into account nearly any factor that had any economic or financial effect. ${ }^{29}$ The IMF no longer had to focus on a mere few factors that could affect currency exchange rates, but now a variety of seemingly tangential factors could become an important driver of a nation's currency value and exchange rate. ${ }^{30}$ Today, the IMF defines its purposes as:

$[\mathrm{T}] \mathrm{o}$ promote international monetary cooperation through a permanent

23. Previdelli \& De Souza, supra note 21.

24. Gottfried Haberler, The International Monetary System After Jamaica and Manila, WeltwirtschaftLiches ARChIV 1, 1 (1977).

25. Daniel D. Bradlow, Rapidly Changing Functions and Slowly Evolving Structures: The Troubling Case of the IMF, 94 Proc. Of THE ANn. MeEting (AM. Soc. OF INT'L L.) 152, 153 (2000).

26. Definition of Floating Exchange Rate, NASDAQ, https://www.nasdaq.com/investing/ glossary/f/floating-exchange-rate [https://perma.cc/3ASZ-AZKX] (last visited Dec. 30, 2019).

27. Special Drawing Rights (SDR), INT'L MONETARY Fund (Apr. 19, 2018) https://www.imf.org/en/About/Factsheets/Sheets/2016/08/01/14/51/Special-Drawing-Right-SDR [https://perma.cc/L3X8-26PP].

28. $I d$.

29. Barry Eichengreen \& Ngaire Woods, The IMF's Unmet Challenges, 30 J. OF ECON. PERSP. 29, 30 (2015).

30. $I d$. 
institution which provides the machinery for consultation and collaboration on international monetary problems; (ii) to facilitate the expansion and balanced growth of international trade, and to contribute thereby to the promotion and maintenance of high levels of employment and real income and to the development of the productive resources of all members as primary objectives of economic policy; (iii) to promote exchange stability, to maintain orderly exchange arrangements among members, and to avoid competitive exchange depreciation; (iv) to assist in the establishment of a multilateral system of payments in respect of current transactions between members and in the elimination of foreign exchange restrictions which hamper the growth of world trade; (v) to give confidence to members by making the general resources of the Fund temporarily available to them under adequate safeguards, thus providing them with opportunity to correct maladjustments in their balance of payments without resorting to measures destructive of national or international prosperity; (vi) In accordance with the above, to shorten the duration and lessen the degree of disequilibrium in the international balances of payments of members. ${ }^{31}$

Additionally, the IMF has never been a stranger to criticism. ${ }^{32}$ Critics of the IMF have argued IMF programs hinder developing nations, cause increases in government crises, and reduce foreign direct investment inflows. " The two main criticisms addressed in this Note are IMF conditionality and "mission creep." IMF conditionality is simply the conditions attached to IMF loans. "Mission creep" is a term utilized to explain how the IMF's power has expanded throughout the years to encompass nearly all factors for consideration when determining loans. ${ }^{35}$ When the global financial scene changed from pegged exchange rates to floating exchange rates, the IMF's scope expanded from purely economic considerations to a variety of non-economic factors that could in some ways influence the economy (i.e. human rights, labor policy, government, etc.). ${ }^{36}$

\section{B. IMF Conditionality}

One of the main criticisms of the IMF and its activities is the presence and strength of the conditions imposed on IMF loans. ${ }^{37}$ According to the IMF Articles

31. Articles of Agreement of the IMF, supra note 4, at art. 1.

32. Willett, supra note 1, at 598.

33. See generally Axel Dreher \& Martin Gassebner, Do IMF and World Bank Programs Induce Government Crises? An Empirical Analysis, 66 INT'L ORG. 329, 330 (2012); Devesh Kapur, The IMF: A Cure or a Curse?, ForEIGN POL'y 114, 114-129 (1998), Nathan M. Jensen, Crisis, Conditions, and Capital: The Effect of International Monetary Fund Agreements on Foreign Direct Investment Inflows, 48 J. OF CONFLICT RESOL. 194, 194-210 (2004).

34. Bradlow, supra note 25, at 153, 154.

35. Id.

36. Id.

37. IMF, Conditionality in Fund Supported Programs-Purposes, Modalities, and Options 
of Agreement,

The Fund shall adopt policies on the use of its general resources, including policies on stand-by or similar arrangements, and may adopt special policies for special balance of payments problems, that will assist members to solve their balance of payments problems in a manner consistent with the provisions of this Agreement and that will establish adequate safeguards for the temporary use of the general resources of the Fund..$^{38}$

This conditionality can take a variety of forms, particularly because conditions are largely based on negotiations between member states and the IMF. ${ }^{39}$ IMF conditions may include, for example, a ceiling on government borrowing, minimum level of federal government primary balance, or a minimum level of international reserves. ${ }^{40}$ The IMF takes various criteria into account when determining the appropriate conditions to attach to its loans, including "prior actions, quantitative and structural performance criteria, indicative targets and structural benchmarks, and program and financing assurances reviews." ${ }^{\prime 1}$ Quantitative performance criteria are conditions that are always related to quantifiable macroeconomic variables that the government authorities can control. These include conditions relating to international reserves, government spending and balances, and external borrowing. ${ }^{42}$ Structural performance criteria, in contrast, are non-quantifiable in nature and serve the purpose of assessing program implementations. These types of criteria may include building social safety nets, strengthening public financial management, or improving the way the financial sector operates. ${ }^{43}$

Conditionality exists for five main reasons: (1) as a tool of enforcement for governments to reform; (2) to make governments pursue policies that would otherwise not be pursued; (3) as a method of creating confidence in lending and solving information asymmetry problems; (4) to control the way the IMF's aid is spent; (5) to address moral hazard problems - if a struggling nation receives a loan, what incentive do nations have to change the factors that landed the nation in its struggling status? $?^{44}$ Anne Krueger, First Deputy Managing Director for the IMF, summed up this problem explaining, "Moral hazard remains a concern. Private institutions may be encouraged to lend and invest recklessly — or at least more than they should - by the belief that the Fund will ensure that their debtors

for Reform, para. 2 (Jan. 29, 2009).

38. Articles of Agreement of the IMF, supra note 3, at art. $5 \S 3(\mathrm{a})$.

39. IMF, Strategy, Policy, and Review Dept., 2011 Review of Conditionality, Background Paper 1: Content and Application of Conditionality, § 3(a) para. 31 (June 18, 2012).

40. IMF, Conditionality in Fund Supported Programs, supra note 37.

41. Id. at 2 .

42. IMF, Conditionality in Fund Supported Programs, supra note 37.

43. Id.

44. Axel Dreher, IMF Conditionality: Theory and Evidence, 141 PuB. CHOICE 238, 240-41 (2009). 
can repay them." ${ }^{45}$

However, conditionality only works if it is enforced ${ }^{46}$, and even then there are criticisms that conditions imposed are too harsh and can actually harm nations in the long run. ${ }^{47}$ For example, Gino Brunswijck draws a connection between recent IMF conditions in European states and protests regarding rising costs of living and tax restructuring. He also finds that IMF conditions, especially austerity measures, hinder or eliminate health-spending and reduces access to healthcare services. $^{48}$

The Asian Financial Crisis provides a clear example of the shortcomings of IMF conditionality even when the conditions are followed. ${ }^{49}$ During the Asian Financial Crisis, the IMF attached a range of conditions that addressed structure, like privatization and labor market liberalizations. In the case of Indonesia, a nation that stringently followed IMF conditionality, the Indonesian government ultimately collapsed in part because of the conditions. ${ }^{50}$ Unlike Indonesia, Malaysia refused to take IMF loans during the crisis. Malaysia implemented its own restructuring efforts through capital controls and restrictions on the convertibility of its domestic currency. ${ }^{51}$ Because Malaysia avoided the IMF, the nation protected itself from the harshest effects of the crisis and fared better than many of the adjacent nations in recovering. ${ }^{52}$

However, there is a more common story regarding IMF conditionality. Even when conditions are imposed, there is no absolute guarantee that those conditions will be followed. From an internal review, the IMF found that the request for conditionality waivers since 1995 were, on average, $13 \%$ for quantitative and $37 \%$ for structural performance criteria. $81 \%$ of programs from 2002-2007 applied for a waiver at some point during the program's arrangement. ${ }^{53}$ This means that although the IMF is setting out and imposing conditions, its debtor nations are not implementing the full amount of changes required by the IMF. ${ }^{54}$ The question is, then, what is the point of conditionality if the vast majority of

45. Anne Krueger, First Deputy Managing Director, IMF, A New Approach to Sovereign Debt Restructuring, Address Given at the National Economists' Club Annual Members' Dinner (Nov. 26, 2001)(transcript available at https://www.imf.org/en/News/Articles/2015/09/28/04/53/ sp112601).

46. Id. at 238. Dreher, supra note 44, at 238.

47. Gino Brunswijck, Unhealthy Conditions: IMF Loan Conditionality and its Impact on Health Financing, Eur. Network ON DeBT \& Dev. 3 (Nov. 28, 2018), https://eurodad.org/files/ pdf/1546978.pdf [https://perma.cc/NBG2-ATRL].

48. Id. at 23 .

49. See generally Ross P. Buckley \& Sarala M. Fitzgerald, An Assessment of Malaysia's Response to the IMF During the Asian Economic Crisis, SingAPORE J. Of Legal Stud. 96, 96-116 (2004), Eichengreen \& Woods, supra note 29, at 37, 39, Narine, supra note 14, at 68, 70.

50. Eichengreen \& Woods, supra note 29, at 39.

51. Narine, supra note 14, at 70.

52. Id.

53. IMF, Conditionality in Fund Supported Programs, supra note 37, at 14.

54. Id. 
nations simply receive waivers and never actually implement the reforms? Critics argue that these waivers actually create uncertainty because it can indicate that the member's performance is failing. ${ }^{55}$ For example, Graham Bird claims "the implementation of programmes could conceal a fall in compliance with structural conditions that it makes by the increased use of waivers," $" 56$ and the IMF itself even admits that "waivers are sometimes an indication of failure and sometimes of successful adaptation of changing circumstances." ${ }^{57}$ Additionally, when the IMF reviews programs for completion, it allows the conditions to be deemed "complete" even when nations have received waivers from conditionality. This sends a message that the completion of IMF conditions is not actually as important as it may seem. ${ }^{58}$

\section{The Fall of the Gold Standard and Mission Creep}

Originally, IMF conditionality was intended for remedying the economic conditions that led a country to need IMF assistance. ${ }^{59}$ As a result, these conditions often focused on economic policies that ensured compliance with the established exchange rate. ${ }^{60}$ Part of the changes enumerated in the Bretton Woods Act included substantially constraining the role of gold in the international financial system. ${ }^{61}$ While the United States Dollar was fixed to $\$ 35$ per ounce of gold, all other currencies were measured in relation to the dollar. ${ }^{62}$ The IMF was established partially to keep nations' exchange rates fixed to the USD/gold standard. ${ }^{63}$ When states wished to join the IMF, they were required to agree to keep their exchange rates pegged and could only be adjusted with the IMF's agreement. ${ }^{64}$

In 1971, President Nixon announced that the United States would not convert dollars at the established exchange rate. While the move did not alter the price of gold or the United States Dollar, this move was the beginning of the end for the fixed exchange between gold and the dollar. ${ }^{65}$ In 1972, the "Smithsonian Agreement" devalued the United States Dollar from $\$ 35$ per ounce of gold to $\$ 38$ per ounce of gold. However, during this time the United States neither sold nor purchased any gold. This is because at the rates set, the United States would have

55. Id. at 9 .

56. Graham Bird, Reforming IMF Conditionality, 10 WORLD ECON. 81, 97 (July-Sept. 2009).

57. IMF, The Modalities of Conditionality—Further Considerations, para. 5 (Jan. 8, 2002).

58. Id.

59. Eichengreen \& Woods, supra note 29, at 39.

60. Id.

61. Craig K. Elwell, Cong. Res. Serv., R41887, Brief History of the Gold Standard IN THE United States 11 (2011).

62. Id. at 11-12.

63. Id.

64. Cooperation and Reconstruction (1994-71), INT'L MONETARY Fund, https://www.imf. org/external/about/histcoop.htm [https://perma.cc/TZX8-RV5A] (last visited Mar. 22, 2020).

65. ELWELL, supra note 61, at 13. 
to either decrease the purchasing power of the dollar, or redeem more dollars than the nation had in its gold reserves. ${ }^{66}$ Because of these issues, the dollar "floated," meaning it was not fixed to any currency or gold. ${ }^{67}$

When the Gold Exchange Standard was finally abolished, the rigid categories that affected exchange rates were abolished and the scope of which IMF was entitled to condition its loans was vastly increased. ${ }^{68}$ This created a striking backlash, with the change described as "intrusive, ineffectual, and counterproductive." " Additionally, the change also resulted in a split into "borrowing" and "non-borrowing" IMF members. Those who could maintain their own exchange rates and reserves were separate from those who needed the IMF's aid. ${ }^{70}$ IMF influence, then was really only persuasive over the "borrowing" members. The IMF could influence "non borrowing" members, but only through "persuasion and voluntary compliance." ""1

One of the criticisms that followed as a result of the new floating exchange rate was "mission creep." Mission creep is the systemic shift of an organization away from its original mandate. ${ }^{72}$ Because the IMF was established during the Gold Exchange Standard, a financial regime that is no longer present, it is natural that the IMF's organizational oversight has changed. However, The IMF itself has admitted that "mission creep" has resulted in worse policy advice than from the IMF's traditional core areas of policy: macroeconomic and balance-of-payments, that the increase in conditions actually resulted in a reduction in effectiveness in policy recommendations. ${ }^{73}$ It also claims that the IMF's mission creep conflicts with concepts of national sovereignty and specialization. For example, the IMF sees climate change, inequality and financial supervision as items within the purview of its mandate. ${ }^{74}$

\section{The AIIB \& Asian Monetary Fund}

Unlike the IMF, which was established through a post-war convention, the AIIB has a long history of growth and change before the institution came to be

66. Id.

67. Id.

68. Bradlow, supra note 25, at 153.

69. Eichengreen \& Woods, supra note 29, at 39.

70. Deena Khatkhate, Reforming the IMF in a New Global Order, 43 ECON. \& POL. WKLY. 32,33 (2008).

71. Id.

72. Sarah Babb \& Ariel Buira, Mission Creep, Mission Push, and Discretion in Sociological Perspective: The Case of IMF Conditionality, Paper presented at the XVIII G24 Technical Group Meeting, Geneva, Switzerland (Mar. 8-9, 2004), https:/www.g24.org/wp-content/uploads/ 2016/01/Mission-Creep-Mission-Push-and-Discretion-in-Sociological-Perspective.pdf.

73. Willett, supra note 20, at 600.

74. Rakesh Mohan, Michael Debabrata Patra \& Muneesh Kapur, The International Monetary System: Where Are We and Where Do We Need to Go?, 4 (Int'l Monetary Fund, Working Paper No. 13/224, 2013), https://www.imf.org/external/pubs/ft/wp/2013/wp13224.pdf. 
the international financial institution it is today. The beginnings of the AIIB can be traced as far back as August of 1997, when in the wake of the Asian Financial Crisis; Japan proposed the creation of an Asian Monetary Fund ("AMF")..$^{75}$ With a proposed 100 billion dollars in reserve, the monetary fund was intended to stabilize the Asian economies that were teetering on the brink of financial crisis. ${ }^{76}$ However, the proposal was not welcomed by the United States. The United States Treasury Secretary and Undersecretary both argued that the creation of an AMF would pose a threat to the IMF by lending money with few or weak conditions. ${ }^{77}$ Faced with opposition from the United States, Japan eventually withdrew the proposal. $^{78}$

However, the proposed AMF was just the beginning. In November of 1997, a modified version of the AMF was proposed in Manila, Philippines. This new version of the proposal held the AMF to be a complementary organization to the IMF, but was still rejected. ${ }^{79}$ Although the AMF ultimately never came to fruition, the idea of an Asian Monetary Fund persisted. ${ }^{80}$ Following the IMF intervention into the Asian Financial Crisis and subsequent exacerbation of the financial difficulties through harsh IMF conditionality, Asian nations cast a skeptical view of the IMF and its policies. ${ }^{81}$ Shortly thereafter, the IMF released a report largely condemning the Asian model of development for the crisis and furthering the "Washington Consensus", or western model of development. From there, tensions between Asian nations and the IMF only rose. ${ }^{82}$

As part of an effort to increase self-sufficiency, many developing nations, including developing Asian nations, began creating a series of currency swap agreements. ${ }^{83}$ The most notable of these currency swap agreements was the Chiang Mai Initiative, which ultimately provided the building blocks for the modern-day Asian International Investment Bank. The Chiang Mai Initiative was established in 2000 in order aid member states that faced short-term liquidity crises. $^{84}$ The Chiang Mai Initiative was a network of regional bilateral currency swaps that nations could turn to for short-term loans. It did not have a formal decision-making body, and its arrangements were largely self-managed between

75. John D. Ciorciari, Chiang Mai Initiative Multilateralization, 51 AsIAN SURV. 926, 927-28 (2011).

76. Id.

77. Id. at 928 .

78. Ranjit Sau, IMF on Wrong Track, 33 ECON. \& PoL. WKLy. 2042 (1998).

79. Yong Wook Lee, Japan and the Asian Monetary Fund: An Identity-Intention Approach, 50 INT'L STUd. QUARTERLY 339, 358 (2006).

80. Id. at 359.

81. Raj M. Desai \& James Raymond Vreeland, Global Governance in a Multipolar World: The Case for Regional Monetary Funds, 13 InT'L STUd. REV. 109, 113 (2011).

82. Narine, supra note 14, at 72-73.

83. Lee, supra note 79, at 359.

84. Howard Loewen, Institutional Interplay between the Chiang Mai Initiative and the International Monetary Fund, 13 EUR. J. OF EAST ASIAN STUD. 50, 61 (2014). 
the member states. ${ }^{85}$

In 2009, the Chiang Mai Initiative expanded into multilateral swap arrangements. This shift, aptly called the Chiang Mai Initiative Multilateralization, or CMIM, included all the ASEAN states and Korea, China, and Japan. ${ }^{86}$ The core objections of this new agreement were "(i) to address balance-of-payments and short-term liquidity difficulties in the region and (ii) to supplement the existing financial arrangements." ${ }^{\circ 7}$ Its reserves initially began at one-hundred twenty billion USD and each member was permitted to swap its currency with USD up to the nation's contribution multiplied by its "purchasing multiplier" ${ }^{88}$ Japan and China were the largest contributors, with equal contribution shares. ${ }^{89}$

Then, in 2013, China announced its intention to create its own financial institution: the Asian Infrastructure Investment Bank ("AIIB"). ${ }^{90}$ In its Articles of Agreement, the AIIB's purpose is set forth:

The purpose of the Bank shall be to: (i) foster sustainable economic development, create wealth and improve infrastructure connectivity in Asia by investing in infrastructure and other productive sectors; and (ii) promote regional cooperation and partnership in addressing development challenges by working in close collaboration with other multilateral and bilateral development institutions. ${ }^{91}$

The AIIB was authorized one hundred billion USD in capital reserves. ${ }^{92}$ The amount a member state may borrow ranges from two to eight times its contribution. ${ }^{93}$ Notably, unlike the monetary funds that came before it, the AIIB does not rely on IMF surveillance. ${ }^{94}$ Instead, the AIIB provides its own terms and conditions for financing. ${ }^{95}$ Additionally, the AIIB sets itself apart in its dedication to only consider economic factors in its loan decisions. ${ }^{96}$ This deviation toward independence sets the AIIB apart as a true competitor, not simply a subordinate organization to the IMF. ${ }^{97}$

85. Id.

86. Id. at 62 .

87. Joint Press Release: The Establishment of the Chiang Mai Initiative Multilateralization (Dec. 28, 2009).

88. Id.

89. Loewen, supra note 84 , at 62.

90. Miran Park, China-led AIIB as a Gradual Modification of Asian Financial Order: Chinese Strategies to Launch New Financial Institution, 24 J. OF INT'L \& AREA STUd. 57 (2017).

91. Articles of Agreement of the AIIB, supra note 10, at art. 1.

92. Id. at art. $4 \S \mathrm{I}$.

93. $I d$. at art. $5 \S \mathrm{I}$.

94. Id. at art. 14

95. Id.

96. Articles of Agreement of the AIIB, supra note 19, at art. $31 \S$ II.

97. Id. at arts. $13,15$. 


\section{E. A Battle of Ideology: The Washington Consensus Versus the Beijing Consensus}

Much of the IMF's decision making is based on an ideological approach known as the "Washington Consensus." ${ }^{98}$ Characterized by neoliberal economics, which believe that "markets are the most efficient and productive way through which to allocate resources and create wealth." 99 The Washington Consensus also believes that governments should not directly interfere with market activities, but should provide a stable foundation for which market activities can occur. ${ }^{100}$ The success of a nation, then, is based upon its desire to subject itself to the market. ${ }^{101}$ Its general tenets, nicknamed the "ten commandments" are as follows: "(1) fiscal discipline, (2) re-ordering public expenditure priorities, (3) tax reform, (4) liberalizing interest rate, (5) liberalization of inward foreign direct investment, (6) trade liberalization, (7) a competitive exchange rate trade, (8) privatization, (9) deregulation, and (10) property rights." 102

The Beijing Consensus, though, is not nearly as rigid in form and theory as the Washington Consensus. ${ }^{103}$ The Beijing Consensus is characterized by three main categories: "financial support for the state sector, restrictions on private sector development, and tight political controls." 104 The Beijing Consensus is also notable in its experimentation-based approach to economic success. ${ }^{105}$ It has also been hypothesized that the emergence of the AIIB will lend credence to the Beijing Consensus and further a "doctrine of non-interference" which purports to attach low, if any conditions to its loans. ${ }^{106}$ This doctrine is stated within Article 31(2) in the AIIB's Articles of Agreement, which states that the Asian Investment Infrastructure Bank should not interfere in any political matters of any member state, nor should it be influenced by any consideration that is not economic. ${ }^{107}$ Human rights, for example, cannot be taken into consideration when determining loan recipients. ${ }^{108}$

While it is not clear whether or not the AIIB will officially espouse a socalled "Beijing Consensus" over the Washington Consensus, the differences between China's approach to development and the Washington Consensus

98. Narine, supra note 14 , at 71.

99. Id.

100. $I d$.

101. Id.

102. Philip Arestis, Washington Consensus and Financial Liberalization, 27 J. OF PosT KEYNESIAN ECON. 252 (2004).

103. Yasheng Huang, Debating China's Economic Growth: The Beijing Consensus or The Washington Consensus, 24 ACAD. OF MgMt. Persp. 31 (2010).

104. Id. at 33 .

105. Id. at 31 .

106. Daniel C.K. Chow, Why China Established The Asia Infrastructure Investment Bank, 49 VAND. J. of TRANSNAT'L L. 1256, 1289 (2016).

107. Articles of Agreement of the AIIB, supra note 10, at art. $31 \S$ II.

108. Id. 
ideology provides for some guidance. Other nations may lean toward the AIIB in favor of the IMF because of its difference in approach to development, or to avoid the all too infamous conditions that come with IMF lending. Nations that have human rights, labor, or environmental concerns may favor the AIIB because of its decision to only take economic considerations into account when deciding loan disbursements. It is even possible that simply because the AIIB is different and not the IMF, and does not carry with it the history of the IMF, that nations may favor the AIIB over the IMF. Regardless of the effects, in the coming years these two competing ideologies will continue to compete within the international financial sphere, and time will tell which financial institution and its ideology will prevail.

\section{EVIDENCE OF UNITED STATES CONTROL}

\section{A. IMF Structure Favors United States}

Following the end of World War II, the United States was in a position of great power. It is not a surprise, then, that when nations gathered for the Bretton Woods Convention, the United States was able to bargain for an institutional makeup and institutional policies that were favorable to the United States. ${ }^{109}$ Evidence of the United States' influence is clear within the IMF's Articles of Agreement, with the IMF's Executive Board initially allowing for five of the twelve Executive Directors to be appointed by the five nations that have the highest quotas. ${ }^{110}$ The remaining seven Executive Directors consisted of five Executive Directors elected by members who were not entitled to appoint a member and a remaining two Executive Directors who would be elected by members of the American Republics. ${ }^{111}$ It is important to note that as membership with the IMF grew, the Executive Directors grew in number to 24 and with the 2010 IMF quota reforms; the composition of the Board of Executive Directors has changed to an all-elected board. ${ }^{112}$

\section{B. The United States Uses the IMF to Advance National Interests}

Even with the all-elected membership, each Executive Board member is responsible for a collective of nations, with the nations that have the five highest quotas still having a single Executive Board member represent only that nation. ${ }^{113}$ As a result, these five Executive Board members are able to respond aligned with the needs and policies of one individual nation, while the Executive Board members who are elected to regions have to take into account a variety of policy

109. Ayse Kaya, Power and Global Economic Institutions 30 (2015).

110. U.N. Monetary and Financial Conference, Final Act and Related Documents, U.N. Doc. A/CONF.55, at 42 (July 22, 1944) [https://perma.cc/XMT9-KMC7].

111. Id.

112. Articles of Agreement of the IMF, supra note 4, at art. 12.

113. IMF Executive Directors and Voting Power, InT'L MonetARY Fund https://www.imf. org/external/np/sec/memdir/eds.aspx [https://perma.cc/UW2X-U9AK] (last visited Dec. 30, 2019). 
agendas and needs to find a solution that is agreeable to all the nations the member represents. ${ }^{114}$ The distribution of power then, still greatly favors the United States and the remaining four nations that hold the largest quotas after the United States.

Aside from the structure of the Executive Director Boards, the structure of the IMF surveillance also raises concerns. According to Article IV of the IMF's Articles of Agreement, the IMF,

[S] hall exercise firm surveillance over the exchange rate policies of members, and shall adopt specific principles for the guidance of all members with respect to those policies. Each member shall provide the Fund with the information necessary for surveillance, and, when requested by the Fund, shall consult with it on the member's exchange rate policies. ${ }^{115}$

This mandate has taken the form of the aptly named "Article IV consultations" which are conducted yearly by the IMF and its member states. ${ }^{116}$ Article IV consultations address a variety of macroeconomic concerns, including structural and monetary issues, foreign exchange, and fiscal and financial policies. ${ }^{117}$ However, these mandatory reviews are not conducted through a oneway evaluation process. Article IV consultations are a "two-way policy dialogue with country authorities." 118 The IMF meets with the political and financial decision makers to evaluate the nation's economic policies and standing. Then, if the nation consents, the information from these meetings is published and made public. ${ }^{119}$

The inclusive nature of Article IV consultations allows for nations to participate and may reduce the perception that the IMF is an overly restrictive institution that forces nations to sacrifice sovereignty. However, participation by the political and financial elites also opens the door for an uneven playing field between nations with higher quotas and presumably more power, and nations with lesser quotas and presumably less power. The International Monetary Fund and its directors are also permanently headquartered in Washington, DC, which calls into question if IMF decision makers are more incentivized to bend to the United States' desires. ${ }^{120}$ The United States may be able to politically pressure the IMF and its directors for favorable policies, or be better positioned to withstand countervailing political pressure from the IMF. J. Lawrence Broz and Michael Brewster Haws found an example of United States domestic politics entering the IMF through bank lobbying. ${ }^{121}$ Domestic banks lobby for the IMF, and in return,

114. Copelovitch, supra note 5, at 55-56.

115. Articles of Agreement of the IMF, supra note 4, at art. 4, § 3(b).

116. IMF, Supporting a Balanced Global Recovery, Annual Report 2010, at 28 (Oct. 2010).

117. IMF, Promoting Inclusive Growth, Annual Report 2017, at 33 (2017).

118. $I d$.

119. Id.

120. Id. at 5 .

121. Broz \& Hawes, supra note 7 , at 1 . 
the United States influences the Fund to better protect nations where American banks are located. ${ }^{122}$ Another example of the United States withstanding potential pressure could be found within the IMF's Article IV consultations.

Part of the Article IV consultation, the Financial Sector Assessment Program ("FSAP"), is only mandatory for nations that the IMF deems "systemically important." 123 According to the IMF, systemic importance is determined by a nation's "interconnectedness" in relation to its size. ${ }^{124}$ Prior to 2010, FSAP was entirely voluntary. Currently, all nations not "systemically important" can elect, or not elect, to participate. ${ }^{125}$ The Financial Sector Assessment Program is conducted every five years and includes a financial stability assessment and a financial development assessment. ${ }^{126}$ It assesses the strength of a nation's financial sector, the quality of the nation's structure of regulation and supervision, and the nation's ability to cope with financial crises. ${ }^{127}$ The voluntary nature of these assessments for more advanced economies is clearly shown in the case of the United States. The United States experienced a massive financial crisis in 2008 that affected the entire global economy. ${ }^{128}$ However, the United States' never experienced a Financial Sector Assessment until 2010. ${ }^{129}$ One could posit that the reason no financial assessment occurred until this time was a result of the United States' ability to withstand pressure from the IMF to submit to such evaluations. ${ }^{130}$

\section{Voting Power \& Quotas}

The most apparent area of the United States' influence over the IMF is in the IMF's quota system. IMF quotas determine access to financing, subscriptions, and most importantly, voting rights. ${ }^{131}$ Currently, each nation is given a number

122. Id.

123. Press Release, IMF Expanding Surveillance to Require Mandatory Financial Stability Assessments of Countries with Systemically Important Financial Sectors, No. 10/357, (Sept. 27, 2010), https://www.imf.org/en/News/Articles/2015/09/14/01/49/pr10357 [https://perma.cc/Z4ASPHAQ].

124. Id.

125. Financial Sector Assessment Program (FSAP), InT'L MonETARy Fund https://www.imf. org/external/np/fsap/fssa.aspx (last visited Dec. 30, 2019) [https://perma.cc/SLM5-DJ49].

126. Id.

127. Id.

128. Manik L. Shrestha \& Marco Marini, Quarterly Revisions in G-20 Countries: Evidence from the 2008 Financial Crisis, IMF Working Paper (2013).

129. Supporting Documents Country FSAPs, InT'L Monetary Fund, https://www.imf. org/external/np/fsap/fsap.aspx?countryname=united+states (last updated Mar. 20, 2020) [https://perma.cc/7AKR-D4PS].

130. See generally, Broz \& Hawes, supra note 7; Independent Evaluation Office of the IMF, Aspects of Financial Sector Surveillance During the Crisis, BP/14/08 (Oct. 8, 2014).

131. IMF Quotas, INT'L MONETARY Fund (Mar. 8, 2019) https://www.imf.org/en/About/ Factsheets/Sheets/2016/07/14/12/21/IMF-Quotas [https://perma.cc/54ST-7GRF]. 
of base votes and then a number of votes based off the nation's quota share. ${ }^{132}$ The largest quota to the IMF is, by far, the United States. Currently, the United States' quota share stands at $17.46 \%$, with the next five largest contributors being Japan $(6.48 \%)$, China $(6.41 \%)$, Germany $(5.60 \%)$, France $(4.25 \%)$, and the United Kingdom (4.24\%). ${ }^{133}$

Because the majority of important decisions within the IMF must be passed with an $85 \%$ majority, this gives the United States not only an advantage, but also a de facto veto power. ${ }^{134}$ Both formally and informally, such marked differences in power gives the United States a unique edge. Formally, resolutions of the IMF that require an $85 \%$ majority, like quota reforms, cannot be passed without the United States' approval. ${ }^{135}$ Informally, the United States can withstand political pressures from the IMF, or put its own political pressure on the IMF to enact favorable or repeal unfavorable resolutions. Such a case occurred regarding the 2010 quota reforms - the United States leveraged its position in the IMF and refused to approve the 2010 quota reforms until the IMF repealed the systemic risk exemption to the debt sustainability criterion of the exceptional access framework. ${ }^{136}$ This exemption was used during the Grecian financial crisis and essentially said that if the risk of not providing a loan would destabilize the global economy, large loans may be approved even if there are questions on whether that loan could ever be paid back. ${ }^{137}$ Another informal advantage deriving from the United States' quota power is its influence on other member states of the IMF. The closer a nation is economically with the United States, the more likely a member will experience a favorable shift in IMF quota during quota reviews. ${ }^{138}$ Nations who wish to improve their position with the IMF, then, would be inclined to align themselves with the United States.

\section{FORMULA FOR DETERMINING GLOBAL ECONOMIC POSITION}

\section{A. The IMF Formula}

Prior to 2008, there was no standardized formula for determining a nation's quota. Instead, the IMF employed five separate quota formulas-The "Bretton Woods formula", Scheme III, Scheme IV, Scheme M4, and Scheme M7. ${ }^{139}$ Each

132. Id.

133. IMF Members' Quotas and Voting Power, and IMF Board of Governors, INT'L MONETARY Fund https://www.imf.org/external/np/sec/memdir/members.aspx\#1 (last visited Dec. 30, 2019) [https://perma.cc/PG5W-NNQ6].

134. See generally Articles of Agreement of the IMF, supra note 4; id.

135. IMF Members' Quotas and Voting Power, and IMF Board of Governors, supra note 133.

136. Consolidated Appropriations Act, Pub. L. No. 114-113, § 9005 (2015).

137. Id.

138. KAYA, supra note 6.

139. These four formulae were as follows: Bretton Woods: $\mathrm{Q} 1=(0.01 \mathrm{Y}+0.025 \mathrm{R}+0.05 \mathrm{P}$ $+0.2276 \mathrm{VC})(1+\mathrm{C} / \mathrm{Y})$, Scheme III: $\mathrm{Q} 2=(0.0065 \mathrm{Y}+0.0205125 \mathrm{R}+0.078 \mathrm{P}+0.4052 \mathrm{VC})(1+\mathrm{C} / \mathrm{Y})$, Scheme IV: Q3 $=(0.0045 \mathrm{Y}+0.03896768 \mathrm{R}+0.07 \mathrm{P}+0.76976 \mathrm{VC})(1+\mathrm{C} / \mathrm{Y})$, Scheme M4: Q4 = 
calculation would then be multiplied by an "adjustment factor" so that the sum of the calculations of the members would equal the sum derived from the Bretton Woods formula. ${ }^{140}$ A nation's calculated quota would be the higher of the two results that came from the Bretton Woods formula and the average of the lowest of the two remaining calculations. ${ }^{141}$ The formulae used were not consistent, however, among member states. Different formulae were used for different member states and only the Bretton Woods formula actually applied to all member states. ${ }^{142}$ Quota determinations were largely backwards - first, an overall quota increase would be decided upon, and then the distribution of the increase would be determined among the member states. ${ }^{143}$ This resulted in the quota formulae existing to essentially fit a number that had already been decided, so each nation's quota was "normalized" through the Bretton Woods formula to achieve the desired number. ${ }^{144}$

The issues surrounding the quota set were initially mitigated through the 2008 quota reforms. Through these reforms, a single formula was derived. It incorporated a blend of Purchasing Power Parity (PPP) GDP and GDP at market rates, openness, variability, reserves, and a compression factor that is then rescaled to sum to $100 .{ }^{145}$ The modern formula used is: $(0.5 \mathrm{Y}+0.3 \mathrm{O}+0.15 \mathrm{~V}$ $+0.05 \mathrm{R})^{\wedge} \mathrm{k}$, where $\mathrm{Y}$ is GDP, $\mathrm{O}$ is openness, $\mathrm{V}$ is variability, $\mathrm{R}$ is reserves, and $\mathrm{k}$ is the compression factor of $.95 .{ }^{146}$

GDP remains the main determinant of a nation's quota, sitting at a $50 \%$ weight in the current formula. ${ }^{147}$ GDP is seen as the most important indicator of a nation's ability to contribute to the IMF, so it is natural that GDP would hold the most weight within any quota formula. ${ }^{148}$ However, there is debate on which GDP, or what measure of GDP blend, should be incorporated. ${ }^{149}$ Currently, GDP

$0.005 \mathrm{Y}+0.042280464 \mathrm{R}+0.044(\mathrm{P}+\mathrm{C})+0.8352 \mathrm{VC}$ and Scheme M7: $\mathrm{Q} 5=0.0045 \mathrm{Y}+0.05281008 \mathrm{R}$ $+0.039(\mathrm{P}+\mathrm{C})+1.0432 \mathrm{VC}$ where for all formulas, $\mathrm{Y}=\mathrm{GDP}$ at current market prices for a recent year, $\mathrm{R}=$ twelve month average of gold, foreign exchange reserves, SDR holdings, and reserve positions in the IMF for a recent year, $\mathrm{P}=$ annual average of current payments (goods, services, income, and transfers for a recent five year period, and $\mathrm{VC}=$ variability of current receipts, defined as one standard deviation from the centered five year moving average, for a recent 13 year period. IMF, Quotas-Updated Calculations and Data Adjustments, Staff Paper (July 11, 2007).

140. Id.

141. Id.

142. KAYA, supra note 6 , at 64 .

143. Id.

144. Id.

145. IMF, Quotas_Data Update and Simulations, Staff Reports (Aug. 2016). https://www. imf.org/ /media/Websites/IMF/imported-full-text-pdf/external/np/pp/eng/2016/_080916.ashx [hereinafter August 2016 Report][https://perma.cc/8GW3-PMBR].

146. Id.

147. Id.

148. Id.

149. IMF, Reform of Quota and Voice in the International Monetary Fund-Report of the Executive Board to the Board of Governors, para. 7 (Mar. 28, 2008). 
is calculated as a blend of PPP GDP (40\%) and GDP at market rates $(60 \%){ }^{150}$ Economies that are classified as emergent economies tend to have higher rates of PPP GDP, while advanced economies tend to have higher market GDP rates. ${ }^{151}$

The second factor of the formula, openness is calculated as the annual average of the sum of current payments and current receipts for a five-year period. This includes goods, services, income, and transfers. ${ }^{152}$ Openness is included in the formula as a result of the belief that nations that are more open to trade and financial flows, as a result more open to the world economy, would be incentivized to promote global financial stability more than nations what are less open to the world economy. ${ }^{153}$ In the formula, it is the second highest weighted variable behind GDP, reflecting its importance. ${ }^{154}$ This variable aids less developed and emerging nations more than it aids advanced economies, because ironically, advanced economies are less "open" by calculation than less developed and emerging economies. ${ }^{155}$ Openness is also positively related to income levels, so as nations gain income, their openness calculation reflects the gains and subsequently, the IMF formula reflects the gains as well. ${ }^{156}$ The largest beneficiaries of an inclusion of an openness calculation are small, advanced economies - they are connected enough in trade and financial flows that their openness number can be double their GDP share. ${ }^{157}$ However, there have been some setbacks identified with an openness variable, for instance that it is very possible to count financial flows twice, especially when there is intra-currency trade. Members of the European Union, then, would artificially benefit more from the openness variable's inclusion. ${ }^{158}$

The third factor of the formula, variability, is calculated as a standard deviation from the centered three-year trend over a thirteen-year period. It exists to measure the variability of current receipts and net capital flows. ${ }^{159}$ Variability was included as a reflection of a given nation's resistance, or lack thereof, of balance of payment shocks (i.e. financial crises) and measures the subsequent predicted need of the IMF's resources. ${ }^{160}$ Compared to the other calculations, variability is one of the most complicated, and there has been a general trend against the inclusion of variability in future quota formulae. ${ }^{161}$ The reason for

150. IMF Quotas, supra note 131.

151. Id.

152. Id.

153. Id.

154. Id.

155. IMF, Quotas—Data Update and Simulations, Staff Reports (Dec. 2016) https://www. imf.org/ /media/Websites/IMF/imported-full-text-pdf/external/np/pp/eng/2016/_080916.ashx [hereinafter December 2016 Report][https://perma.cc/8GW3-PMBR].

156. Id.

157. Id.

158. Id.

159. Id.

160. December 2016 Report, supra note 155.

161. Id. 
removing variability does not only result from the fact that calculating variability is complicated; Examinations conducted by the IMF showed that the measure of variability increases instability in the current calculated quota shares and does not accurately serve to predict how likely a nation will utilize IMF resources. ${ }^{162}$

The fourth factor, reserves, is a twelve month average over a given year of official reserves, including SDR holdings, monetary gold, foreign exchange, and the nation's reserve position in the IMF. ${ }^{163}$ The inclusion of reserves in the IMF formula reflects the fact that following the 1997 Asian Financial Crisis, many developing nations began stockpiling reserves to protect against economic shocks, and these nations are now better positioned through their reserves to withstand such shocks. ${ }^{164}$ Advanced economies benefit little from an inclusion of reserves, but emerging economies benefit much more from reserves. ${ }^{165}$

Lastly, there is the compression factor of .95. ${ }^{166}$ The compression factor exists to reduce the dispersion between each nation's quota shares. ${ }^{167}$ The compression factor attempts to control for the role of a nation's size in the quota formula. It benefits every nation except for the 9 largest economies-United States, China, Japan, Germany, United Kingdom, France, India, Russia, and India, who take a loss as a result of compression. ${ }^{168}$ Percentage points from the largest economies are redistributed to all the other members of the IMF, with emergent economies and less developed nations being the biggest beneficiaries. ${ }^{169}$ Like PPP GDP, the compression factor will remain in the quota formula until 2028. ${ }^{170}$ Opinions are still split between the Executive Directors on whether the compression formula should be increased or decreased. ${ }^{171}$

While the new single formula greatly simplified and consolidated the previous five formulae, it did not come without debate. ${ }^{172}$ As a result of differing opinions regarding the inclusion of PPP GDP and a compression factor, the Executive Board included both factors in the IMF formula for 20 years. ${ }^{173}$ Even during the 2010 quota reforms, it was recognized that the 2008 quota formula would need to be revised. ${ }^{174}$ This revision was to be part of the Fifteenth General Review of Quotas, which should have occurred January 2013. ${ }^{175}$ However, this date was consistently pushed back and as of the time of this paper, the $15^{\text {th }}$

162. August 2016 Report, supra note 145.

163. Id.

164. Desai \& Vreeland, supra note 81 , at 110.

165. IMF Quotas, supra note 131.

166. Id.

167. Id.

168. Id.

169. Id.

170. IMF, Reform of Quota and Voice in the International Monetary Fund, supra note 149.

171. IMF Quotas, supra note 131.

172. IMF, IMF Quota and Governance Reform - Elements of an Agreement (Oct. 2010).

173. IMF, Reform of Quota and Voice in the International Monetary Fund, supra note 149.

174. IMF Quotas, supra note 131.

175. Id. 
General Review of Quotas is slated to occur in $2019 .{ }^{176}$

\section{B. $15^{\text {th }}$ General Review of Quotas -Potential 2019 Changes}

One of the prevailing reasons for such a focus on the IMF quota structure is that the IMF quota structure determines voting rights within the institution. Voting rights, in turn, are the power a nation has to pass or not pass IMF initiatives ${ }^{177}$ Much of the criticisms around the IMF center on its quota system, and that an alteration of its quota system to better favor emerging nations would signal that the IMF is an independent institution free from United States' influence. ${ }^{178}$

According to the IMF's Articles of Agreement, "The Board of Governors shall at intervals of not more than five years conduct a general review, and if it deems it appropriate, propose an adjustment, of the quotas of the members. It may also, if it thinks fit, consider at any other time the adjustment of any particular quota at the request of the member concerned." ${ }^{\prime 179}$ The last review of quotas, the Fourteenth General Review, occurred in 2010. In the review, the Board of Governors requested the Executive Board to complete the Fifteenth General Review in January of 2014. Work began on the Fifteenth General Review of Quotas on January 30, 2013. ${ }^{180}$ However, the changes as part of the Fourteenth General Review could not be implemented until the United States, which has veto power, approved them. ${ }^{181}$ This approval did not occur until 2015. ${ }^{182}$ The Fifteenth General Review as a result was delayed eventually until the Spring Meetings of 2019, and at the latest at the 2019 Annual Meetings. ${ }^{183}$

\section{Are the 2010 Changes Enough?}

Among the many changes that occurred as a result of the Fourteenth General Review of quotas, the main changes were a $100 \%$ increase in overall quota, tripling of each nation's basic votes to account for a total $5 \%$ of the IMF's votes,

176. IMF, Fifteenth General Review of Quotas-Report of the Executive Board to the Board of Governors, para. 4, (Oct. 21, 2016).

177. Articles of Agreement of the IMF, supra note 4, at art. $12 \S 5$.

178. See generally Colin I. Bradford, Johannes F. Linn, \& Ralph C. Bryant, Experts Critique Proposal for International Monetary Fund Quota Reform, Brookings (Apr. 9, 2008), https://www.brookings.edu/opinions/experts-critique-proposal-for-international-monetary-fundquota-reform/ [https://perma.cc/D9M9-QLDD]; Acha Ikechukwu A., International Monetary Fund's Quota System and Voting Rights: A Need for Review, GLOB. J. of Fin. \& Econ. Mgmt. 119, 122-123 (2011); Eichengreen \& Woods, supra note 29, at 47, 48.

179. Articles of Agreement of the IMF, supra note 4, at art. $3 \S 2$ (a).

180. IMF, 2010 Reforms and Fifteenth General Review of Quotas-Report of the Executive Board to the Board of Governors, para. 3, 4 (Jan. 20, 2015).

181. Id.

182. Consolidated Appropriations Act, Pub. L. No. 114-113, § 9005 (2015).

183. See IMF, Fifteenth General Review of Quotas, supra note 176. 
and an all-elected Executive Board. ${ }^{184}$ Each of these changes benefit emerging nations and less developed economies, but they are not sufficient to withstand the increasing competition from the Asian Infrastructure Investment Bank. In order to withstand growing pressure from the Asian Infrastructure Investment Bank, the IMF must address its "crisis of legitimacy." Institutional legitimacy is essentially the right or power of an entity to "issue and enforce rules in the ways that it does." ${ }^{185}$ Legitimacy is only as effective as its constituents' obedience. The IMF has continually experienced a "crisis of legitimacy" long before the ascent of the Asian Infrastructure Investment Bank, and the crisis of legitimacy could be said to have contributed to the Asian Infrastructure Investment Bank itself. ${ }^{186}$ In order to regain its legitimacy, the IMF must modify its quota and governance system further. Many of the reforms in 2010 were a step in the right direction, but many aspects of the reform still ring hollow.

Shifting the Executive Board to an all-elected entity certainly aided in the perception of equality among members. However, the shift did not change the fact that the top IMF contributors have their own individual member, elected or not, while the other nations are divided by region and represented by a single executive board member. ${ }^{187}$ Voting among the executive board members as well gives emerging and less developed economies only a partial victory. Voting through the Executive Board is mostly through consensus, meaning that the majority of the times, votes are never actually cast. ${ }^{188}$ The International Monetary and Financial Committee (IMFC) does not conduct any formal votes, operating entirely by consensus. The Managing Director, head of both the IMF Executive Board and the IMF staff is appointed by the Executive Board, usually by consensus. ${ }^{189}$ "Consensus" in the IMF context means that if enough executive directors holding a sufficient number of votes to pass the policy are in favor for a policy, the policy will pass without vote. ${ }^{190}$ This results in Executive Directors from nations that are originally against the policy attempting to mitigate by using a change in position as a bargaining chip to get at least some favorable concessions. ${ }^{191}$

Another concern is that quotas are only as effective as the frequency with which they are used. A quota formula is useless if it is applied and subsequently ignored. Emergent and less developed economies have made great strides in

184. IMF, IMF Quota and Governance Reform -Elements of an Agreement, (Oct. 31, 2010).

185. N.P. Adams, Institutional Legitimacy, J. OF PoL. PHIL. 84-102 (2018).

186. See generally, ARIEL BuIRA, The Bretton Woods Institutions: Governance Without Legitimacy?, in Reforming The Governance Of The IMF ANd The World BANK 7-44 (2016).

187. IMF Executive Directors and Voting Power, InT'L MONETARY Fund, https://www.imf. org/external/np/sec/memdir/eds.aspx (last visited, Dec. 30, 2019) [https://perma.cc/4VWP-M6F4].

188. How the IMF Makes Decisions, InT'L Monetary Fund (Mar. 8, 2019) https://www.imf.org/en/About/Factsheets/Sheets/2016/07/27/15/24/How-the-IMF-Makes-Decisions [https://perma.cc/5V66-5WHT].

189. KAYA, supra note 6.

190. Id.

191. IMF, IMF Governance -Summary of Issues and Reform Options, § 4 (2009). 
better representation in quota calculations, but if the quota formula is ultimately ignored or modified to fit a bigger scheme, then the 2008 quota formula is a pyrrhic victory. The IMF has made clear that its quota formulae, and subsequent single formula, are just a guideline. ${ }^{192}$ Part of the IMF's reasoning away from using the quota formula as a hard and fast rule is likely because the current IMF quota formula actually increases the calculated quota share of the largest economies. ${ }^{193}$ Advanced economies, including the United States, have voluntarily foregone increases in IMF quota shares that the nations are entitled to according to the IMF quota formula. ${ }^{194}$ Instead of asking nations to voluntarily relinquish their calculated quota shares, it would be more beneficial to increase the compression factor that redistributes quota shares from the largest shareholders to the smallest shareholders and increase the consistency with which the quota formula is used.

Lastly, and most importantly, the changes that resulted from the Fourteenth General Review of quotas are insufficient to withstand pressure from the Asian Infrastructure Investment Bank because the IMF still lacks institutional legitimacy. The main issue that has arisen time and time again regarding the IMF is not only its actions, but also the perceived hand behind those actions - the United States. ${ }^{195}$ It is no secret that nations have voiced concerns over the relationship between the United States and the IMF. ${ }^{196}$ Through the Fourteenth General Review, these nations did regain representation in voting and quota shares, however, not all nations appear convinced that the IMF and United States are wholly separate entities. Brazil, for example, has sought funding from sources that are "more able to be guided by Brazil's overall national priorities and not those of specific interest groups or other governments." 197

\section{Alternative Quota Formula Proposal}

Work on the Fifteenth General Review of quotas has been conducted since January of 2013. ${ }^{198}$ Since January 2013, almost yearly reports have been released, including a 2016 report that consisted of a series of simulations based on different variations of revised quota formulae and how they affected various IMF member

192. IMF, Quotas_Data Update and Simulations, Staff Reports para. 12 (Sept. 2016).

193. Id., at para. 24.

194. IMF, IMF Quota and Governance Reform-Elements of an Agreement, supra note 184, at 5 .

195. See supra Section III.

196. Id.

197. David A. Mares, Harold A. Trinkunas, Aspirational Power: Brazil On the Long ROAD TO GLOBAL INFLUENCE 120 (2016).

198. See generally IMF, Quotas-Data Update: Statistical Appendix, Policy Papers (July 2015); IMF, Quota Formula —Data Update and Further Considerations, Policy Papers (July 2014); IMF, Quota Formula-Data Update and Further Consideration, Policy Paper (July 2013) [hereinafter July 2013 Report]. 
states. ${ }^{199}$ Among the proposed formulae, ten were simulated, each of which dropped variability as a variable in the revised IMF formula. ${ }^{200}$

From there, proposals included: current openness measure, dropping variability, and dividing the weight of variability evenly between GDP and openness, with different combinations of the GDP blend; current openness measure, dropping variability and dividing its weight between GDP (2/3) and openness $(1 / 3)$ with different combinations of GDP blend; current openness measure, dropping variability, giving all the weight of variability to GDP, with different combinations of GDP blend; current openness measure, dropping variability, weight of openness reduced to .25 , with different combinations of GDP blend; current GDP blend, dropping variability, and splitting the weight of variability evenly between GDP and openness, and different openness measures; current GDP blend, dropping variability, all weight of variability to GDP, with different openness measures; current GDP and openness measures, increasing the compression factor to 0.925 , and a lower compression factor of $0.975 .{ }^{201}$ Prior staff papers had also explored additional options for a quota revision, including a cap on how much a nation may benefit from the openness variable within the IMF quota formula. ${ }^{202}$ Of the formulae, a combination of dropping variability, capping the gains from openness, and placing the weight of variability into a 50/50 split of PPP GDP and market rate GDP would be the best formula combination for EMDC and LICs, and would be the best formula for the IMF's Fifteenth General Review of quotas. ${ }^{203}$

Variability is dropped in every iteration of the formula proposal simulation and there is little support to allow the variable to remain in the formula, although some do support dropping the variable on the condition that its weight is redistributed in a particular way, for example redistributing in a way that protects the IMF's poorest members. ${ }^{204}$ IMF research has concluded that variability has failed to achieve its purpose of predicting how likely a nation will be to utilize the IMF's resources. ${ }^{205}$ No studies have been able to show an empirical link between the variability variable and a likelihood of a nation to use IMF resources. ${ }^{206}$ Luckily, the openness variable is highly correlated to the variability variable, meaning many of the factors measured in openness cover the factors measured in variability. ${ }^{207}$

One of the more striking issues with the current IMF formula is that the

199. See IMF Quotas, supra note 131; IMF, Quotas-Data Update: Statistical Appendix, Policy Papers (July 2015); IMF, Quota Formula —Data Update and Further Considerations, Policy Papers (July 2014); July 2013 Report, supra note 198.

200. $I d$.

201. IMF Quotas, supra note 131.

202. July 2013 Report, supra note 198.

203. IMF Quotas, supra note 131.

204. Id.

205. July 2013 Report, supra note 198.

206. Id.

207. Id. 
current quota formula continues to increase calculated quota shares for advanced economies. This increase is enough that the largest shareholders voluntarily relinquish their calculated quota share increases. ${ }^{208}$ While advanced economies benefit less from openness, they do still benefit -23 out of the 26 categorized advanced economies gain from the utilization of the openness variable. In addition, the openness variable is extremely skewed, indicating that some members benefit at a vastly disproportionate rate in comparison to others. ${ }^{209} \mathrm{~A}$ cap to openness would help to control for some of the disproportionate gains from smaller advanced economies but still allow for openness to benefit emerging and less developed economies. ${ }^{210}$ In the 2013 IMF data report, two types of caps to openness were identified: a cap on the absolute level of openness relative to market GDP and a cap on the boost a member receives relative to its GDP blend. Advanced nations are more likely to be affected by the second cap by virtue of its usage of the GDP blend. ${ }^{211}$

The next change in formula should be to increase the weight of GDP as a whole and to increase PPP GDP within the GDP blend. The increase in weight to overall GDP should come from the variability factor. The increase in PPP GDP within the blend should result in a 50\% PPP GDP and 50\% market rates GDP combination. This would strike a balance between market rates reflecting an ability to contribute to the IMF and the fact that the majority of emerging economies have higher PPP GDP rates than advanced economies. ${ }^{212}$

In addition to the above variables, the compression factor is a vital tool in ensuring that the dispersion between nations is not as severe. In its simplest terms, it is the variable that takes from the rich and gives to the poor. ${ }^{213}$ The compression factor is a controversial subject, but because it is required in the $15^{\text {th }}$ General Review of quotas, it will remain a topic of discussion. ${ }^{214}$ The compression factor should for the foreseeable future, remain the same. Simulations indicate how emerging and advanced economies would gain and/or lose from an increase or decrease in the compression factor. There remains a larger consideration when looking at equalizing, to an extent, the largest and smallest quota shareholders - an ability to actually pay their quota. A smaller compression factor would result in losses to emerging economies and aid in the over representation of several advanced economies. ${ }^{215}$ However, increasing the compression factor in conjunction with the above suggestions results in the formula that gives the one of the largest possible gains to less developed and emerging nations. This is not

208. IMF, Reform of Quota and Voice in the International Monetary Fund-Report of the Executive Board to the Board of Governors, para. 9 (Mar. 28, 2008).

209. July 2013 Report, supra note 198.

210. Id.

211. Id.

212. IMF, Quotas—Data Update and Simulations, Staff Reports A, para. 4 (Sept. 2016).

213. IMF, Quotas_Data Update and Simulations, Staff Reports B, para. 22 (Sept. 2016).

214. Id. para. 8 .

215. See data set 4, Tables 14-15; IMF, Quotas-Data Update and Simulations, Staff Reports (Sept. 2016). 
necessarily a bad thing, until it is taken into account that the IMF will likely need an overall quota increase as part of the $15^{\text {th }}$ General Review.

The IMF has three lines of defense against financial shocks: quotas, multilateral borrowing agreements, and bilateral borrowing agreements. Under normal circumstances, the IMF utilizes funds from its quotas to provide financing for nations in crisis. ${ }^{216}$ If the IMF's quota resources may be insufficient, the IMF can utilize multilateral borrowing arrangements to aid in financing. These arrangements are made up of IMF member states that agree to lend to the IMF in extraordinary circumstances. ${ }^{217}$ Currently, the IMF has one multilateral borrowing arrangement in effect: the New Arrangements to Borrow. ${ }^{218}$ The second of the multilateral borrowing arrangements, the General Arrangement to Borrow, expired December 28, 2018. ${ }^{219}$ The third and final line of defense is the bilateral borrowing arrangement. If quotas and multilateral arrangements are insufficient to provide funds to nations in need, for example during a systemic global financial crisis, bilateral borrowing arrangements could be invoked. ${ }^{220}$ In 2016, bilateral borrowing agreements commenced with total commitments reaching SDR 316 billion, or approximately $\$ 460$ billion USD. These arrangements are slated to end in 2019 with an option to extend to 2020 if the members of the bilateral borrowing arrangement consent. ${ }^{221}$ For reference, the IMF's current quota total reaches SDR 477 billion, or 677 billion in USD. ${ }^{222}$ With the bilateral swap arrangement system nearly reaching the total of the IMF's current quota, the IMF would be wise to increase its quota share to offset the financial hit that will come from the expiration of the bilateral swap arrangements. The question is, then, how much should the IMF increase its overall quota share in the $15^{\text {th }}$ General Review of quotas?

The IMF has proposed two options: a $70 \%$ and a $115 \%$ overall quota increase. $^{223}$ Out of the two options considered, the larger would be the most beneficial for the IMF as a whole. The New Arrangements to Borrow has been extended to November 2022, but there is no guarantee that the arrangement will continue beyond that date. ${ }^{224}$ A $70 \%$ increase in overall quota would amount to SDR 330 billion, which is just under 460 billion USD. A 70\% increase in overall quota would allow for the IMF to keep its current lending capacity following the 2019 expiration of bilateral swap arrangements. However, if the Fund wants to protect itself against the possibility of losing both its multilateral and bilateral

216. Where The IMF Gets Its Money, INT'L MONETARy Fund (Mar. 8, 2019) https://www.imf.org/en/About/Factsheets/Where-the-IMF-Gets-Its-Money [https://perma.cc/X4VLMJMF].

217. $I d$.

218. Id.

219. Id.

220. Id.

221. Id.

222. Where The IMF Gets Its Money, supra note 216.

223. December 2016 Report, supra note 155.

224. Id. 
swap arrangements, it will need to increase its overall quota to $115 \% .{ }^{225}$ An increase of $115 \%$ would "broadly restore the ratio of quotas relative to an average of relevant economic indicators to levels observed in previous general reviews of quotas." 226

A concern then arises in addressing the balance between a quota and a nation's ability to pay that quota. With the gains in the proposed formula, emerging and less developed countries will have an increase in both voting power and financial contribution requirements. Because of the current instability regarding the future of multilateral swap arrangements beyond 2022, and the expiration of bilateral swap arrangements in 2019, the IMF as a financial institution would be best suited to account for the financial losses in increasing its overall quota to mitigate its anticipated losses. In doing so, it is possible that with a formula that gives maximum gains to emerging and less developed nations will be unwieldy at best and unsustainable at worst. As such, the compression factor within the proposed ideal formula should remain the same as the compression factor in the previous 2008 IMF formula, and PPP GDP should remain at a 50/50 split with market rates GDP.

While there are alternatives that allow for poorer countries to meet the increase in quotas, the alternatives only go so far. ${ }^{227}$ When IMF quotas are changed, nations must produce twenty five percent of the increase in SDR. However, the IMF can allow for the payment to be made in the currencies of other members, or in the member's own currency. ${ }^{228}$ The problem with this alternative is that in the event of a global financial crisis, it is the SDR basket that is used, meaning only the United States Dollar, Euro, Chinese Yuan, Japanese Yen, and Pound Sterling are largely usable. ${ }^{229}$

\section{HOW COMPETITION FROM THE AIIB CAN INCENTIVIZE THE UNITED STATES TO REEVALUATE}

\section{A. Voting Structure}

It is recognized that the proposed quota would result in a drastic shift in formal power within the IMF. The question then arises, why would advanced economies, specifically the United States, want to risk power? Even more so, why would the United States react to the AIIB's presence by relinquishing its power within the IMF? To answer both these questions, it must be first examined why the AIIB is an unprecedented rival to the IMF, and then how the United States benefits from the proposed changes.

The Asian Infrastructure Investment Bank stands on the shoulders of the

225. Id.

226. Id.

227. See Articles of Agreement of the IMF, supra note 4, at art. $3 \S 3(\mathrm{a})$.

228. Id.

229. Where The IMF Gets Its Money, supra note 216. 
Chiang Mai Initiative, a regional monetary fund. ${ }^{230}$ Regional monetary funds do many of the same functions of the IMF. They hold reserves of currencies and provide liquidity should its member states need funding. ${ }^{231}$ Regional monetary funds can act as a gateway to IMF funding, providing an extra level of support before nations are forced to turn to the IMF. ${ }^{232}$ However, many regional monetary funds currently incorporate or complement the IMF. ${ }^{233}$ The reasons for including the IMF vary among regional monetary funds. For larger loans, regional monetary funds may have to draw upon the resources of the IMF. ${ }^{234}$ The Chiang Mai Initiative, for example, required its members to submit to the IMF for any request above $20 \%$ of the CMI's available currency. ${ }^{235}$ The African Monetary Fund appears to be the result of small IMF quota share, and as a result exists more as a supplementary organization rather than a competitive organization to the IMF. ${ }^{236}$ South America attempted to withdraw from the IMF and create its own regional fund, the Banco del Sur, but its members did not have sufficient credit to access the international markets, and the bank has yet to be capitalized. ${ }^{237}$

\section{B. How the AIIB Differs from the Regional Monetary Funds}

Unlike regional monetary funds and bilateral or multilateral currency swaps, the AIIB stands wholly independent of the IMF, existing with its own surveillance function, capital funds, and detailed governance organization. ${ }^{238}$ The AIIB also has a much larger capital stock than regional monetary funds, holding at its current state one hundred billion USD. ${ }^{239}$ The AIIB combines the benefits of a regional monetary fund, namely, regional identity and awareness, with the stability of an international financial institution. Because the AIIB is focused largely on Asia, it is uniquely positioned to aid in Asian financial crises. Furthermore, because a large majority of members in the AIIB are still regional, there is greater incentive for member states to make careful financial decisions. ${ }^{240}$

Most importantly, though, the AIIB fills a gap within the global financial scene - the gap of a true competitor to the IMF. While the IMF struggles to maintain its legitimacy in the modern day, the AIIB appears to be growing its legitimacy as an institution exponentially. What originally began as an organization by Asian nations for Asian nations has expanded to include nonregional members that wish to join. Twenty-six non-regional nations, including

230. See supra Section II.

231. Desai \& Vreeland, supra note 82, at 115.

232. $I d$.

233. Id. at $117,118$.

234. Id. at 117.

235. Id.

236. Id. at 118 .

237. MARES \& TRINKUnAS, supra note 197.

238. See generally Articles of Agreement of the AIIB, supra note 10.

239. Id. at art. 4.

240. Desai \& Vreeland, supra note 81, at 114. 
the United Kingdom, Madagascar, Egypt, and Canada have joined the AIIB as of January $21,2019 .^{241}$ The AIIB lacks the history and stigma many of these nations have faced in their experiences with the IMF. Many of the grievances the founding AIIB nations experienced were reflected in the AIIB articles of agreement. For example, Article XIII section 10 states "the bank shall pay due regard to the desirability of avoiding a disproportionate amount of its resources being used for the benefit of any member." ${ }^{242}$ The members of the Board of Governors are unpaid, with the exception of the bank reimbursing expenses related to attending meetings. ${ }^{243}$ From the beginning, the Board of Governors is an elected body and the number of basic votes is $12 \%$, as opposed to the IMF's $5 \% .{ }^{244}$ The AIIB's pull is clear in its membership list: 25 members are nonregional, and account for $1 / 4$ of the voting power within the institution. Nonregional members include major allies to the United States, such as Germany, Britain, Canada, Australia, and South Korea. ${ }^{245}$

\section{Advantages for the United States in Altering Structure of IMF}

The proposed formula is clearly a strategic move for the United States. The United States is now falling into a classification of "declining states," a former hegemonic power that given enough time will be surpassed by rapidly growing emerging nations like China. ${ }^{246}$ The key distinction, though, is that the United States may be down, but it is not out for the count. Likewise, legitimacy regarding the IMF has waned, but it is not completely absent. The United States likely will never retain the power it held post-Bretton Woods in the beginnings of the IMF, but there is still opportunity to retain power and control over some aspects of the global financial markets and IMF.

Politically, giving emerging nations more formal political power within the IMF through increased quota shares is beneficial both domestically and internationally. With a fall in economic position comes a rise in domestic scrutiny. Domestic politicians may be less likely to support multilateral financial commitments like the IMF's New Arrangements to Borrow. ${ }^{247}$ Shifting to the proposed quota formula is beneficial because the United States is able to leverage some of the literal costs of IMF membership onto developing nations. In a very literal sense, the cost of maintenance of the IMF's institution is reduced through an increase in cost dispersion. The United States' spending is likewise reduced (at least in terms of the amount slated for the IMF). ${ }^{248}$

Internationally, a nation with veto power permitting such drastic changes that

241. See Members and Prospective Members of the Bank, supra note 9.

242. See Articles of Agreement of the AIIB, supra note 10, at art. $13 \S 5$.

243. Id. at art. $22 \S 3$.

244. Id. at art. $28 \S 1$ (i).

245. See Members and Prospective Members of the Bank, supra note 8.

246. KAYA, supra note 6, at 28, 30.

247. Id. at 30 .

248. Id. 
appear to benefit only emerging nations will increase legitimacy in the IMF by sending a message to nations that the United States does not intend to use the IMF as a tool to further its policies. Such changes could also show emerging nations a new era of the IMF - one of transparency and fair representation. The $15^{\text {th }}$ general review of quotas could usher in an opportunity to "rebrand" the organization. Because the United States had a hand in the creation of the IMF, it follows that the United States manufactured the IMF in part aligned with its preferred policies. ${ }^{249}$ The United States, then, would likely prefer the continuance of the IMF to an alternative financial institution that was created by another entity. If the value of continuing the IMF as an organization exceeds the harm of a marginal decrease in institutional power, the result would be an accommodation by the United States. The United States would be inclined to agree to relinquish some institutional power in favor of pacifying disgruntled member states. ${ }^{250}$

Even with the proposed quota formula change, the United States retains its veto. ${ }^{251}$ United States' power is weakened, but it remains the largest shareholder of the IMF. An increase in the quota share and voting rights of emerging and lessdeveloped nations also comes with an increase in surveillance, and to an extent, control. The more involved a nation is in an organization, the more that nation is constrained by the rules and regulations of that organization. Ayse Kaya explains,

[D]eclining states can 'bind' the rising states in institutional settings under which a 'state seeks to exert some control over another state's policies by incorporating it in a web of institutional arrangements.' The more the rising states can be brought into the framework of existing institutions and made to participate in these institutions, the more their actions can be controlled. ${ }^{252}$

What the United States loses in formal political power, it gains in informal political power. As largest shareholder of the IMF, the United States retains its informal political pressure and can utilize that pressure more effectively against nations more involved with the IMF. Previously, the largest shift in political power within the IMF was the 2010 quota reform. ${ }^{253}$ It is difficult to imagine any further drastic economic reforms prior to the creation of the AIIB. From a basic economic standpoint, no entity would leave a position of gain without a perceived greater gain. ${ }^{254}$ Before the AIIB, the United States' hold on the IMF was strong, and resulted in an imbalance of power benefiting the United States. However, the AIIB has modified that balance. In jeopardizing the monopoly of the IMF over

249. Id.

250. Id. at 31 .

251. See illustrative calculation 9, IMF, Quotas-Data Update and Simulations, Staff Reports, 30 (Sept. 2016).

252. KAYA, supra note 6 , at 30 .

253. The 2010 quota reform resulted in a $100 \%$ increase in overall quota share. IMF, IMF Quota and Governance Reform - Elements of an Agreement (Oct. 2010).

254. See Rational Choice Theory, EnCYClOPEDIA BRITANNICA, https://www.britannica.com/ topic/rational-choice-theory (last visited Dec. 30, 2019) [https://perma.cc/D7TB-95CL]. 
the global financial sector, there are new considerations for the United States in its cost-benefit analysis. Now, there is great benefit to the maintenance of the IMF as a strong, if not the strongest, international financial organization. In pacifying the long-held complaints of emerging nations, the United States would be able to mitigate some of its decline in economic importance and relevance that may come with a new competitor.

\section{PROSPECTS FOR THE FUTURE}

Because the emergence of the Asian Infrastructure Investment Bank is an unprecedented occurrence, the future is rife with possibility. Many questions remain: Will the AIIB succeed long-term? Will there be two IMF-like organizations? Will more competitors join as regional financial organizations mimic the AIIB's structure? Will the IMF remain, or will it be surpassed? Only time will tell for many of these questions, but some evidence suggests that the AIIB is here to stay.

The AIIB has two major advantages to its position: It is now, at the time of this Note, three years old. ${ }^{255}$ The AIIB has surpassed the pitfalls that destroyed or stalled its predecessors. ${ }^{256}$ Additionally, it was the "right thing at the right time." Simply by virtue of being an international financial organization that is not the IMF, the AIIB could potentially gain an initial legitimacy boost from the aggrieved IMF member nations. However, the AIIB has yet to experience a global financial crisis. Some risks are still present for the fledgling international financial institution. For example the AIIB's capital shares only reaches a $1 / 4$ of the IMF's current SDR quota. China's share of the AIIB's voting rights reaches $26.5 \%$, resulting in veto power. ${ }^{257}$ The issues nations experienced with the IMF and its relation to the United States may be present in the AIIB, just with China as the hegemonic state as opposed to the United States.

\section{A. Changes to the IMF}

While the AIIB is new and relatively inexperienced, the effect of such an organization on the IMF brings to light another consideration: how will the IMF change? The answer is, to some extent, already taking form. The IMF's yearly statistics and data updates have consistently incorporated new calculations and studies to determine the best possible course forward. The IMF has moved to pacify many of the most glaring issues with representation - the Executive Board is an all elected entity, many developing nations and emerging nations have already begun to experience quota increases, and the IMF continues to make strides on increasing transparency. ${ }^{258}$ It is possible that from the example set by the AIIB, the IMF Board of Directors may elect to live outside Washington, DC

255. Articles of Agreement of the AIIB, supra note 10, at art. $58 \S 1$.

256. See supra Section VI.

257. Members and Prospective Members of the Bank, supra note 8.

258. IMF, IMF Quota and Governance Reform -Elements of an Agreement (Oct. 2010); IMF, Promoting Inclusive Growth, Annual Report 2017, at 35 (2017). 
or the IMF may increase the weight of basic votes to match that AIIB's $12 \%$.

The most important change to the structure of the IMF will undoubtedly be the change to the IMF's quota formula. As stated above, it would be in both the IMF and the United States' best interest to combine an overall quota increase of $115 \%$, a cap to the openness variable, and the elimination of the variability factor for which the weight is redistributed to GDP. Further, the GDP blend should be modified to a 50/50 PPP GDP/GDP at market rates as the revised quota formula. This formula should be accompanied by a $115 \%$ increase in overall quota to cover for the possibility of expiration of the New Arrangements to Borrow in 2022. However, with a competitor for finance arrangements, there is a possibility that the IMF may have a reduced need for capital reserves.

\section{B. Changes To the Structure of the Global Financial Scene}

Much like the internal structure of the IMF, many changes have begun to take form in the global financial scene. As a result of many grievances lobbied toward the IMF, the 2010 quota reforms came with large strides in redistributing power. China is now the $3^{\text {rd }}$ largest member of the IMF. ${ }^{259}$ Brazil has looked elsewhere for IMF alternatives and expanded its trade and investments with China. ${ }^{260}$ There have been proposals for two-tiered systems for the co-existence of monetary funds, so it is possible the IMF and AIIB could co-exist. ${ }^{261}$ This likely would be with the IMF remaining as a lender of last resort and the AIIB as a first line of defense against financial distress. Nations may be more likely to initially turn to the AIIB than they would the IMF, and the AIIB may be able to intervene earlier as a result.

A potential third competitor to the AIIB and IMF, the New Development Bank, has begun to take form with its headquarters in Shanghai, China. ${ }^{262}$ This bank has a subscripted capital share of 50 billion USD with 100 billion USD as authorized capital, making it capital-wise approximately the same size lender as the AIIB. ${ }^{263}$ It signed its first loan in December of $2016 .{ }^{264}$ Unlike the Asian Infrastructure Investment Bank, the New Development Bank appears to be approaching its growth model slowly. ${ }^{265}$ Brazil, India, China, Russia, and South America must at all times make up at least $55 \%$ of its voting power, so it by definition will lack representation among member states. ${ }^{266}$

259. IMF, IMF Executive Directors and Voting Power, supra note 113.

260. MARES \& TRINKUNAS, supra note 197.

261. Desai \& Vreeland, supra note 81, at 116.

262. Articles of Agreement of the New Development Bank, art. 4.

263. Id. at art. 2.

264. Press Release, New Development Bank, NDB Signs First Loan Agreement for Financing Shanghai Lingang Distributed Solar Power Project (Dec. 21, 2016).

265. New Development Bank, NDB's General Strategy: 2017-2021, 26 (June 30, 2017) https://www.ndb.int/wp-content/uploads/2017/07/NDB-Strategy-Final.pdf [https://perma.cc/U2EJ4795].

266. Articles of Agreement of the New Development Bank, supra note 262, at art. $8 \S 15$. 


\section{CONCLUSIONS}

Currently, the IMF is facing a crossroads: during a time when it is experiencing a crisis of legitimacy and criticism, a new challenger has appeared. The AIIB appears to provide many of the same functions of the IMF, but does not have the stigma associated with the IMF's past mistakes. If the IMF wishes to stay relevant and withstand the pressure of its newfound competition, it should incorporate an overall increase of $115 \%$ to IMF quotas and include a cap to openness, dropping the variability factor and incorporating its weight into a blend of 50\% PPP GDP and 50\% GDP at market rates.

This is a drastic shift in power from advanced economies to emerging economies, but the most powerful states, specifically the United States, do have incentives that can make such a change feasible. For the United States, increased domestic scrutiny over its international financial relations would create a greater incentive to leverage its literal costs related to its position in the IMF onto emerging nations. That increase in participation from emerging nations, in turn, would also result in greater control for the United States through institutional rules and regulations. Looking forward to the future of the international financial scene, it is likely that the Asian Infrastructure Investment Bank and the IMF will exist in tandem to each other, but there are rising possibilities of even more competitors. Although unlikely, it is possible that in the future the AIIB could serve as a lending option for nations with collateral while the IMF continues to serve conditions-based loans to nations that either do not have collateral or do not wish to give collateral. In this scenario, the two institutions would not necessarily be in direct conflict and would instead provide more choice for debtor nations when the nations take on loans.

With this lending, it is very hard to imagine the AIIB being a truly politically neutral counterpart to the IMF and the criticism that the IMF is politically influenced by the United States. Although the AIIB may not be imposing conditions akin to IMF conditionality, the AIIB taking collateral for some loans still results in a potential political influence. China, in having the largest stake in the AIIB, would then have a physical bargaining chip to potentially utilize in political negotiations. Simply by virtue of having a large stake in the AIIB, China has a natural bargaining power with nations that are member states. Smaller nations seeking favorable initiatives to be passed may try to curry favor with China in hopes that China will vote in line with those initiatives. It is easy for a young institution to claim that it will be a less-biased alternative, but given time the AIIB could very well become the target of the very same criticism that allowed for its entrance into the financial market - that the institution is too influenced by its largest quota-state.

However, the Asian Infrastructure Investment Bank, unlike its predecessors, will remain in the global financial market. Its membership will likely continue to grow, and it is possible that even the United States will eventually come to join 
the institution. There still remains questions on whether the AIIB will press its "Beijing Consensus" ideology upon its debtor nations, or if the AIIB will remain focused on collateral-based lending as opposed to conditions based lending. These remaining questions will be answered in time as the world watches the AIIB stand as a formidable competitor to the IMF. 